Génét. Sél. Evol., 1985, 17 (3), 293-302

\title{
A 1/29 chromosome translocation in Southern African Nguni cattle. The identification, occurrence and origin of the translocation
}

\author{
N.D. NEL *, E.J. HARRIS *, J.E. WEIERMANS *, \\ E.H.H. MEYER* and K. BRIX ** \\ * Animal and Dairy Science Research Institute, \\ Private Bag X2, Irene, 1675, Republic of South Africa \\ ** Department of Genetics, University of the Orange Free State, \\ Bloemfontein, Republic of South Africa.
}

\begin{abstract}
Summary
A $1 / 29$ chromosome translocation was found in 10.2 p. 100 of a sample of 305 Nguni cattle. Investigations into the origin and spread of the translocation show a familial inheritance of the anomaly but give no indication as to the origin of the translocation. The high incidence was achieved despite the associated infertility and absence of artificial insemination which raises the question of a selective advantage in a particular environment. Normal and translocation hetero- and homozygous cattle are being produced in order to investigate this possibility.
\end{abstract}

Key words : Cattle, Nguni, chromosome abnormality, translocation.

\section{Résumé}

Mise en évidence, fréquence et origine de la translocation chromosomique 1-29 dans le bétail Nguni d'Afrique du Sud

La translocation chromosomique 1-29 a été mise en évidence dans 10,2 p. 100 d'un échantillon de 305 têtes de bétail Nguni. L'étude de la diffusion de cette translocation montre un mode de transmission héréditaire mais ne donne aucune indication sur son origine. Cette fréquence élevée a été atteinte en dépit d'une chute corrélative de la fertilité et de l'absence d'insémination artificielle d'où la question posée de l'avantage sélectif que conférait cette translocation dans un milieu particulier. Des animaux normaux et des transloqués homozygotes et hétérozygotes sont actuellement procrés pour tester cette éventualité.

Mots clés : Bovins, Nguni, anomalie chromosomique, translocation. 


\section{Introduction}

The Nguni cattle are the indigenous cattle found along the east coast of Southern Africa, parts of the eastern Transvaal, Swaziland and Kwazulu. The word Nguni is the collective ethnic name for the Xhosa, Zulu and Swazi people who were the original owners of these cattle (EPSTEIN, 1971 a). Nguni cattle are of medium build, cervicothoracic humped with crescent or lyre shaped horns and are classified as Bos indicus of the Sanga type. A prominent feature of the Nguni cattle is the variety of colour patterns found in this breed. The high fertility and apparent tolerance to heat and a number of diseases warrants their inclusion into animal improvement schemes (Nguni CATtLE REPORT, 1950).

The first such scheme, the Bartlow Combine breeding station, was established in Kwazulu on the east coast of Southern Africa in 1950, while a second farm, stocked with cattle from Bartlow Combine, was developed in the Transvaal in the late 1970's. These herds number approximately 1800 and 350 animals respectively. It was during an investigation into gonadal hypoplasia, present in these herds, that a heterozygous $1 / 29$ chromosome translocation was found in a Nguni heifer (MEYER, 1981).

This translocation is the same as that which has been described in more than 40 breeds in various countries of the world (Gustavsson, 1979). Investigations by Gustavsson (1969, 1971 a), Refsdal (1976), Dyrendahl \& Gustavsson (1979), and Kovacs \& CsukLY (1980) show a reduction in the fertility of translocation carrying cattle in comparison to normal cattle under similar conditions. These results are indirectly supported by Gustavsson (1971 b), King \& Linares (1983) and Swartz \& VogT (1983) who found $1 / 29$ translocation carriers in samples of repeat breeder heifers. The reduced fertility of translocation carriers is caused by the production of unbalanced gametes (Logue \& Harvey, 1978 ; Popescu, 1978) and the associated loss of aneuploid embryos in an early stage of pregnancy (KING et al., 1980 ; PoPESCU, 1980). Conversely, studies by Pollock \& Bowman (1974), QueInNeC et al. (1974), BlazaK \& EldRidge (1977), ZAHNER et al. (1979), and STRANZINGER et al. (1981) fail to show significant differences between the fertility of normal and translocation carrying cattle. The different results may be attributed to the genetic control of meiotic segregation and selection against aneuploid gametes in translocation heterozygotes (BLAZAK \& ELDRIDGE, 1977), or to the sample size, location and management of the cattle under investigation, the method used and the interpretation of the results (Kovacs \& CsUKLY, 1980). Despite these differences, most authors are in favour of the removal of translocation carrying cattle from stud herds.

The aim of this study was to investigate the origin, identification and occurrence of the translocation in the 2 Nguni herds. The discussion also speculates on the possibility of a selective advantage for translocation carrying cattle.

\section{Materials and methods}

The bulk of the Nguni cattle used in this study is located on the Animal and Dairy Science Research Institute's farm near Groblersdal in the Transvaal, a province of the Republic of South Africa. The remaining samples were obtained from the Bartlow Combine breeding station in Kwazulu. 
Metaphase spreads were obtained from whole blood lymphocyte cultures adapted from the method described by MoorheaD et al. (1960).

$0.5 \mathrm{ml}$ of heparinised blood was added to $10 \mathrm{ml}$ of culture medium (M 150 or F 10) supplemented with 20 p. 100 foetal calf serum and Concanavaline $A(0.01 \mathrm{mg} / \mathrm{ml}$ of culture). Cultures were incubated for 72 hours at $37.5^{\circ} \mathrm{C}$ and Colcemid $(0.005 \mu \mathrm{g} / \mathrm{ml})$ was added 1.5 hours prior to harvesting. After a hypotonic shock with $6 \mathrm{ml}$ of $0.075 \mathrm{M}$ KCL solution (15 minutes) the lymphocytes were fixed in two changes of Carnoy's fixative (methanol : acetic acid, $3: 1$ ). Slides were prepared by dropping the cell suspension on to cold, wet microscope slides, flamed or air dried and rinsed in distilled water.

The mounted chromosome spreads were stained routinely in 5 p. 100 Giemsa and 20 well dispersed metaphase spreads were studied for structural or numerical aberrations. The co-ordinates and chromosome counts of each spread were recorded. In this way, a total of 305 cattle (Groblersdal : 217 and Bartlow Combine : 88) were studied. The Groblersdal sample, collected over a period of 3 years (1981-1983), included all animals introduced and produced on the farm prior to the discovery and removal of translocation carrier animals from the stud herd. The Bartlow Combine sample of 20 bulls and 68 cows was taken at random from the stud herd (tabl. 1).

TABLE 1

Nguni cattle screened.

Effectif de bétail Nguni analysé.

\begin{tabular}{|c|c|c|c|}
\hline \multirow{2}{*}{ Location } & \multicolumn{3}{|c|}{ Cattle screened } \\
\hline & $0^{\circ} \sigma^{\circ}$ & $\$ q$ & Total \\
\hline Groblersdal & 51 & 166 & 217 \\
\hline \multirow[t]{2}{*}{ Bartlow combine } & 20 & 68 & 88 \\
\hline & 71 & 234 & 305 \\
\hline
\end{tabular}

The chromosomes of animals found to deviate from the standard karyotype were identified by means of $\mathrm{G}$ - and R-banding techniques. C-banding was used to gain information about the centromeric structure of the translocation chromosome.

G-banding : 2 week old slides were immersed in 0.25 p. 100 trypsin in Balanced Salt Solution for 30 to 40 seconds at room temperature. The trypsin solution was adjusted to $\mathrm{pH} 8.0$ with 5 p. 100 sodium bicarbonate. After trypsinization, the slides were dehydrated through a series of alcohol grades, air dried and stained in 5 p. 100 Giemsa. R-banding was obtained by exposing the cultures to 5 -Brdu $(50 \mu \mathrm{g} / \mathrm{ml})$ for 5 hours prior to harvesting. The air dried, rinsed slides were passed through a series of alcohol grades to water, rinsed in phosphate buffer and stained in acridine orange for 15 minutes. After rinsing for 30 minutes, the cells were mounted in a drop of buffer and sealed with nail varnish. Banded metaphase spreads were photographed with Zeiss Epifluorescence equipment on Agfaortho $35 \mathrm{~mm}$ film. 
C-banding : 2 week old slides were placed in $0.2 \mathrm{~N} \mathrm{HCl}$ for 1 hour and then transferred to a 5 p. $100 \mathrm{BaOH}$ solution $\left(50^{\circ} \mathrm{C}\right)$ for periods ranging from 1 to 5 minutes. After rinsing, the slides were incubated for 1 hour in $2 \mathrm{SSC}\left(65^{\circ} \mathrm{C}\right)$, rinsed in water and stained in 5 p. 100 Giemsa for 20 minutes.

The pedigree of each translocation carrier was traced in order to gain information concerning the origin and spread of the translocation and to check the possible de novo occurrence of such a translocation. Only animals with a carefully documented ancestry were used in the combined pedigree. At Groblersdal, translocation carrier cattle were removed from the stud herd and placed in a separate translocation breeding herd established towards the end of 1982. These results will be published at a later date.

\section{Results}

Screening of the metaphase spreads confirmed the presence of 60 chromosomes, consisting of 29 acrocentric autosomal pairs and 1 pair of sex chromosomes. This is in agreement with the findings of numerous authors, the earliest of whom used histological and squash techniques to study cattle chromosomes (KRALlinger, 1927 ; Makino, 1944 ; Melander, 1959). The female is represented by a pair of large submetacentric $\mathrm{X}$ chromosomes while the $N$ guni bull has an $\mathrm{X}$ chromosome and a small submetacentric $\mathrm{Y}$ chromosome.

Karyotypes of Giemsa stained autosomes were arranged according to the relative lengths of the chromosomes. The G-banded chromosomes were arranged according to the standard karyotypes adopted at the Reading Conference (FORD et al., 1980). The $\mathrm{R}$-banded chromosomes were arranged according to the proposals of Di BERARDINo \& IANNUZZI (1982) and Popescu et al. (1982).

The differential staining of the chromosomes facilitates the identification of the homologous chromosome pairs. The G-banding results were generally very poor. The chromosomes are either devoid of bands or have an indistinct fuzzy appearance, both of which make identification impossible. R-banding, on the other hand, proved to be a more reliable method, giving good results (fig. 1). Enlargement of the R-banded chromosomes enables the identification of the participating chromosomes as numbers 1 and 29. The C-banded metaphase spread (fig. 2) shows the centromeric regions of the translocation chromosomes. These chromosomes appear to be monocentromeric under the light microscope.

Differences in the number of chromosomes per metaphase spread led to the discovery of heterozygous $1 / 29$ chromosome translocations in a number of animals. A total of 305 cattle were screened. The incidence of the translocation in the nucleus herds at Groblersdal and Bartlow Combine was found to be 9.7 p. 100 and 11.4 p. 100 respectively, giving an average of 10.2 p. 100 for all Nguni cattle screened (tabl. 2). No translocation homozygous animals were found in this sample.

The translocation, which shows a familial pattern of inheritance, has been traced to 2 bulls (D 230 and I 234) present at the establishment of the Kwazulu herd in the late 1940's (fig. 3). It is possible that these bulls were related. No breeds other than Nguni have been introduced into the herd since that time and one can only speculate on the origin and spread of the translocation in the Nguni cattle. 


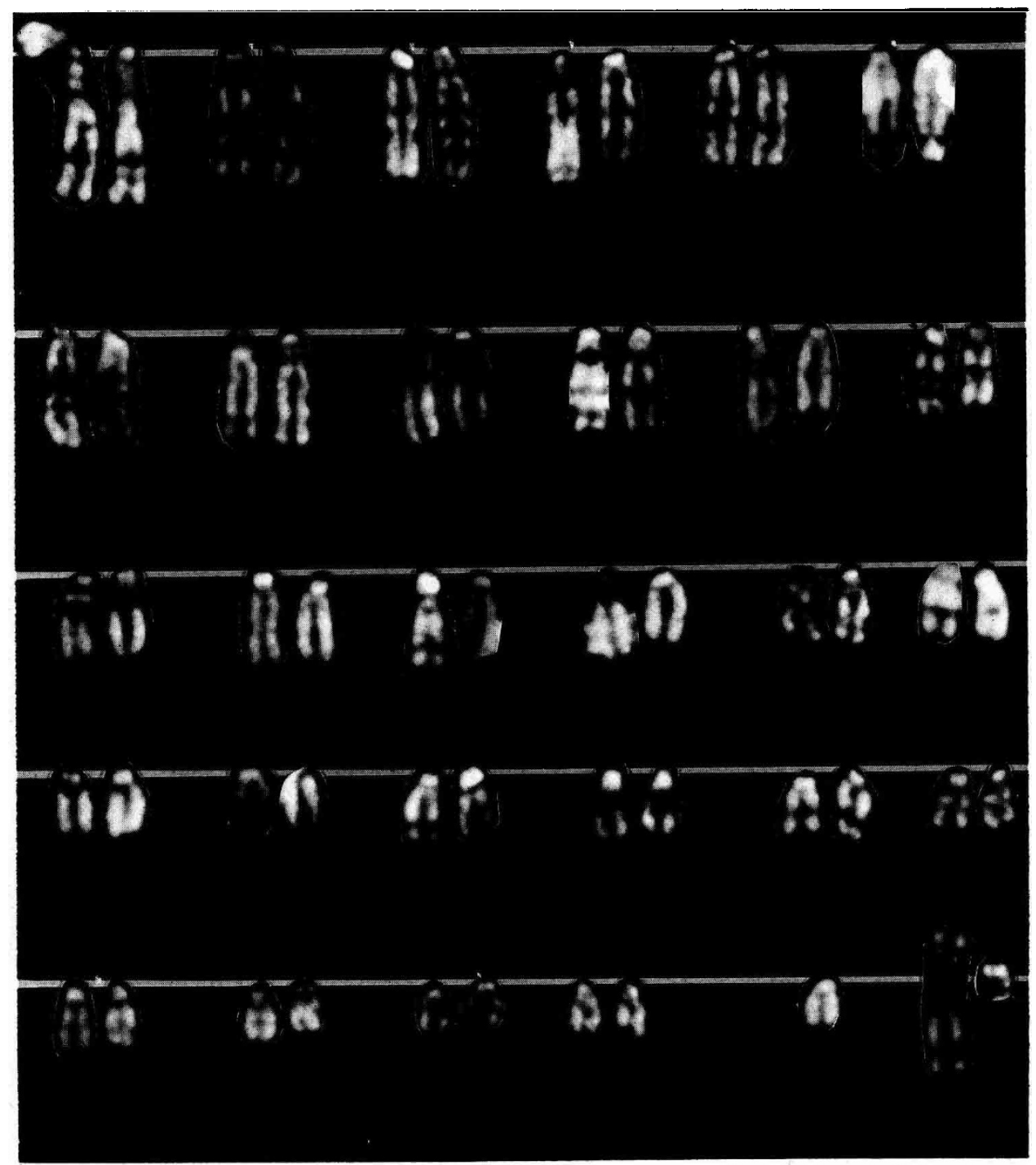

FIG. 1

An R-banded karyotype of a translocation heterozygote bull. Caryotype en bande $R$ d'un taureau hétérozygote transloqué. 


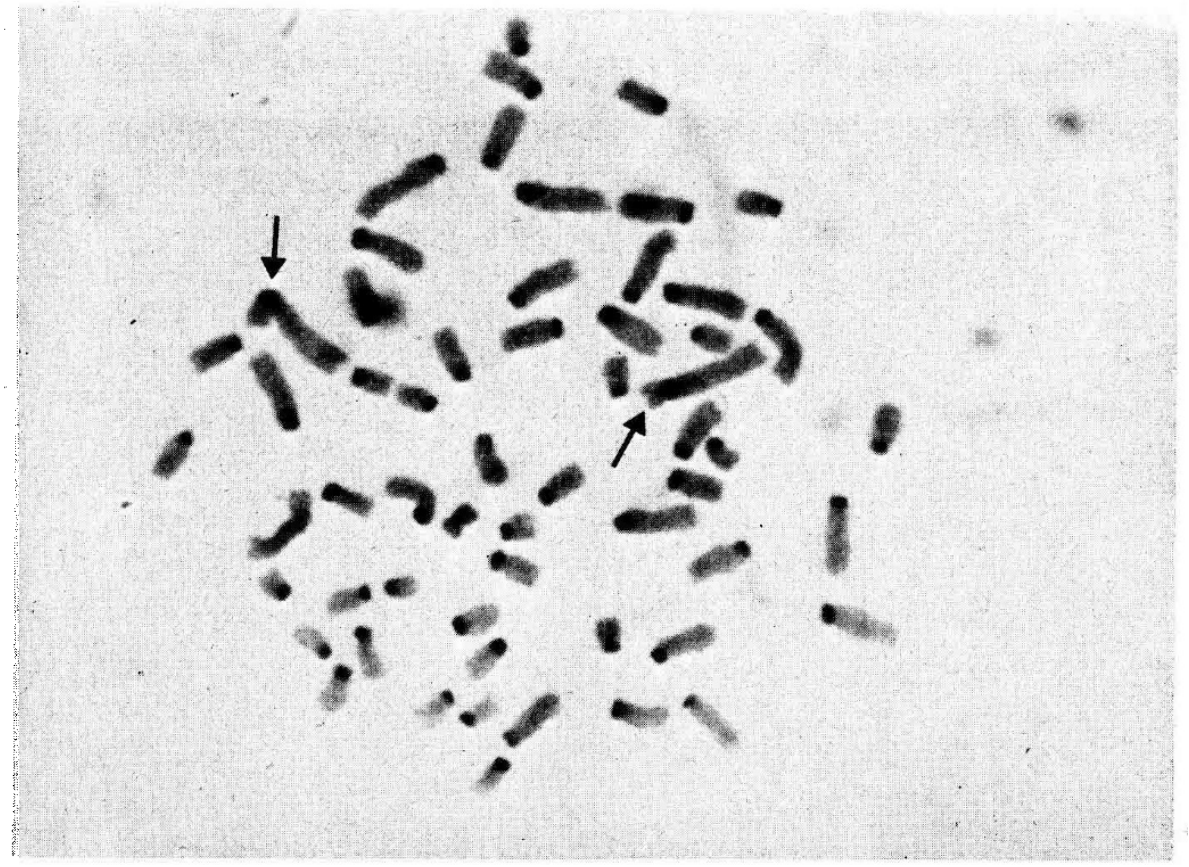

Fig. 2

A C-banded metaphase spread of a translocation homozygous bull* (the arrows show the translocation chromosomes).

Métaphase en bandes $C$ d'un taureau homozygote (les flèches indiquent les chromosomes remaniés).

* This bull was bred from translocation heterozygous parents. Ce taureau est issu de parents transloqués hétérozygotes.

\section{TABLE 2}

The incidence of the 1/29 chromosome translocation.

Fréquence de la translocation chromosomique 1/29.

\begin{tabular}{|c|c|c|c|c|c|}
\hline \multirow{3}{*}{ Location } & \multicolumn{4}{|c|}{ Karyotypes } & \multirow{3}{*}{$\begin{array}{c}\text { Incidence } \\
\%\end{array}$} \\
\hline & \multirow{2}{*}{ Normal } & \multicolumn{3}{|c|}{ Trans. } & \\
\hline & & $0^{\circ} \sigma^{\circ}$ & qq & Total & \\
\hline Groblersdal $\ldots \ldots \ldots$ & 196 & 3 & 18 & 21 & 9,7 \\
\hline \multirow[t]{2}{*}{ Bartlow combine .... } & 78 & 4 & 6 & 10 & 11,4 \\
\hline & 274 & & & 31 & 10,2 \\
\hline
\end{tabular}




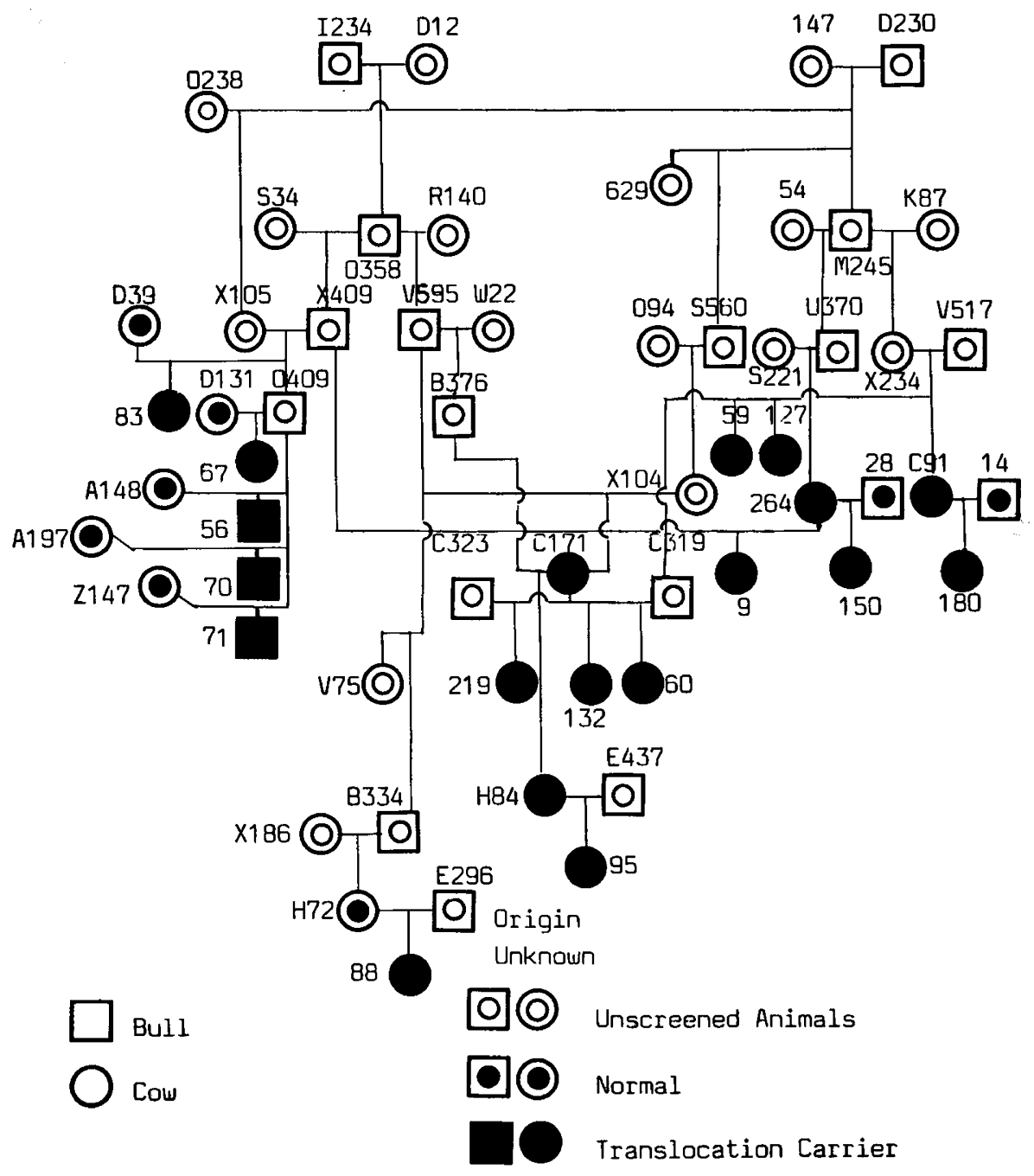

Frg. 3

A combined pedigree of the translocation carriers.

Généalogie des porteurs de la translocation. 


\section{Discussion}

The present study shows both a familial pattern of inheritance and a monocentromeric translocation chromosome. No de novo occurrences have been found in either of the $2 \mathrm{Nguni}$ herds. These findings suggest an ancestral introduction of the translocation from a point of origin, possibly central Europe (HARVEX, 1972 ; NIEBUHR, 1972 ; Gustavsson, 1979). From Europe, translocation carrying cattle could have reached Central and Southern Africa as early as 1000 A.D. (EPSTEIN, 1971 b). Another possibility is the introduction of translocation carrying cattle to Southern Africa by the Dutch and other European Settlers after 1652.

The study of the banded and Giemsa stained metaphase spreads revealed the presence of a $1 / 29$ chromosome translocation in 10.2 p. 100 of the 305 Nguni cattle studied. This relatively high incidence was attained despite the total absence of artificial insemination and the adverse effect on fertility which has been shown in extensive field (Gustavsson, 1969 ; ReFsDal, 1976) and cytological studies (KING et al., 1980 ; Popescu, 1980). The rationale for this is the chance selection of translocation carrying bulls as sires in a herd of restricted size.

A second possibility is that of a selective advantage in a particular environment. If such an advantage does exist, it could, depending on its nature, be of great economic importance. Testing the validity of this hypothesis requires a complete morphological and physiological comparison between normal and translocation heterozygous and homozygous cattle, a study which is presently underway.

In conclusion it may be said that the $1 / 29$ chromosome translocation found in the Nguni cattle is of unknown origin, has a familial pattern of inheritance and is present in approximately 10 p. 100 of the Nguni cattle screened.

Received October 8, 1984.

Accepted February 27, 1985.

\section{Acknowledgements}

We thank the Department of Co-operation and Development (Rep. S. Afr.) and the Kwazulu Government Service for their assistance. We also thank Drs. C.Z. RouX and J.S.J. KrUGer and Messrs. M.M. ScholtZ, J.C. Groenewald, C.B. Enslin and K. Ramsey for their contribution to this study. This paper forms part of an M.Sc. Thesis submitted to the University of the Orange Free State, Bloemfontein, Rep. South Africa, 1984.

\section{References}

Blazak W.F., EldRIDGe F.E., 1977. A Robertsonian translocation and its effect upon fertility in Brown Swiss cattle. J. Dairy Sci., 60, 1133-1142.

Di Berardino D., IANnUzzi L., 1982. Detailed description of R-banded bovine chromosomes. J. Hered., 73, 434-438. 
Dyrendahl I., Gustavsson I., 1979. Sexual functions, semen characteristics and fertility of bulls carrying the $1 / 29$ chromosome translocation. Hereditas, 90, 281-289.

Epstein H., 1971 a. The origin of domestic animals of Africa. 461 pp., Africana Publ. Corp., N.Y., London, Munich.

Epstein H., 1971 b. The origin of domestic animals of Africa. 545 pp., Africana Publ. Corp., N.Y., London, Munich.

Ford C.E., Pollock D.L., Gustasson I., 1980. Proceedings of the First International Conference for the standardisation of banded karyotypes of domestic animals. Hereditas, 92, $145-162$.

Gustavsson I., 1969. Cytogenetics, distribution and phenotypic effects of a translocation in Swedish cattle. Hereditas, 63, 68-169.

Gustavsson I., 1971 a. Culling rates in daughters of sires with a translocation of centric fusion type. Hereditas, 67, 65-74.

Gustavsson I., 1971 b. Chromosomes of repeat-breeder heifers. Hereditas, 68, 331-332.

Gustavsson I., 1979. Distribution and effect of the 1/29 Robertsonian translocation in cattle. J. Dairy Sci., 62, 825-835.

HaRveY M.J.A., 1972. Chromosome abnormalities of cattle in Britain. Vet. Rec., 91, 630.

KING W.A., LINARES T., 1983. A cytogenetic study of repeat-breeder heifers and their embryos. Can. Vet. J., 24, 112-115.

King W.A., Linares T., Gustavsson I., Bane A., 1980. Presumptive translocation type trisomy in embryos sired by bulls heterozygous for the 1/29 translocation. Hereditas, 92, 167-169.

Kovacs A., Csukly S., 1980. Effect of the 1/29 translocation upon fertility in Hungarian Simmental cattle. Proc. 4th Eur. Colloq. Cytogenet. Domest. Anim., Uppsala, June 10-13, 1980, 35-43.

Krallinger H.F., 1927. Über die Chromosomenforschung in der Säugetierklasse. Anat. Anz., 63, 209-214. (Ergänzungsheft).

LoGUe D.N., HaRVEY M.J.A., 1978. Meiosis and spermatogenesis in bulls heterozygous for a presumptive 1/29 Robertsonian translocation. J. Reprod. Fert., 54, 159-165.

Makino S., 1944. Karyotypes of domestic cattle, Zebu and domestic water buffalo. Cytologia, 13, 247-264.

Melander Y., 1959. The mitotic chromosomes of some cavicorn mammals (Bos taurus L., Bison bonasus L., Ovis aries L.). Hereditas, 45, 649-664.

MeYer E.H.H., 1981. Die waarde van chromosomal en biochemiese genetiese merkers vir diereproduksie. Tegnikon, 29 (3/4), 8-12.

Moorhead P.S., Nowell P.C., Mellman W.J., Battips D.N., Hungerford D.A, 1960. Chromosome preparations of leukocytes cultured from human peripheral blood. Exp. Cell Res., 20, 613-615.

Nguni Cattle Report, 1950. Report on indigenous cattle in South Africa. Dept. of Agric., Union of South Africa, 22, Bulletin 311.

NIEBUHR E., 1972. Dicentric and monocentric Robertsonian translocation in man. Humangenetik, 16, 217-226.

Pollock D.L., Bowman J.C., 1974. A Robertsonian translocation in British Friesian cattle. J. Reprod. Fert., 40, 423-431.

Popescu C.P., 1978. A study of meiotic chromosomes in bulls carrying the $1 / 29$ translocation. Ann. Biol. Anim. Bioch. Biophys., 18, 383-389.

Popescu C.P., 1980. Cytogenetics study on embryos sired by a bull carrier of 1/29 translocation. Proc. IVth Eur. Colloq. Cytogenet. of Domest. Anim., Uppsala, June 10-13, 1980, 182-186.

Popescu C.P., RonNe M., Cribiu E.P., Boscher J., 1982. The standardisation of the R-banded karyotype in cattle (Bos taurus L.). Proc. Vth Eur. Colloq. on Cytogenet. of Domest. Anim., Milano-Gargnano, June 7-11, 1982, 172-190.

Queinnec G., Darre R., Berland H.M., Raynaud J.C., 1974. Etude de la translocation 1/29 dans la population bovine du Sud-Ouest de la France : conséquences zootechniques. Proc. 1st World Congr. Genet. appl. Livestock Prod., Madrid, October 7-11, 1974, 3, 131-151. 
REFSDAL A.O., 1976. Low fertility in daughters of bulls with $1 / 29$ translocation. Acta Vet Scand., 17. 190-195.

Stranzinger G., Emler K., Bauer G., Gaillard C., 1981. Konzeptionsergebnisse bei Mischspermaeinsatz von Stieren verschiedener Rassen und Chromosomenzahl. Zuchthygiene, 16, 49-53.

Swartz H.A., Vogt D.W., 1983. Chromosome abnormalities as a cause of reproductive inefficiency in heifers. J. Hered., 74, 320-324.

ZahNer B., Kupfer U., Tschudi P., 1979. Der Einfluss der $1 / 29$ translocation auf die Fruchtbarkeit von Simmentaler Kühen in der Schweiz. Zuchtghygiène, 14, 49-54. 